\title{
CHARACTER EDUCATION WITH ISLAMIC INSIGHTS OF THE NUSANTARA
}

\author{
Siti Yumnah \\ Pancawahana Islamic College, Bagil Pasuruan Indonesia \\ E-mail: sitiyumnah30@gmail.com
}

Received: 09-07-2021 Revised: 20-09-2021 Accepted: 20-10-2021

\begin{abstract}
Islam Nusantara is Islam built with cultural infrastructure. Islam is friendly, polite, integrated with culture as Indonesian civilization. One of the most important efforts in instilling the Islamic culture of the archipelago is through education. So far, people think that the education process has not succeeded in educating the Indonesian people. For this reason, it is necessary to strengthen the values of national character education, by combining Islamic religious values and insight into the archipelago, or commonly called Nusantara Islam-based character education. The purpose of this paper is to find out and instill character education with an Islamic perspective on the archipelago. This paper uses a qualitative research approach using library research methods. Using the library method to collect data, namely collecting data in the form of text that supports this research. Based on the results of the study, it can be concluded that Nusanatara Islam is an Islam based on cultural infrastructure. Then the concept of character education based on Islam Nusantara is pesantren, madrasa, madrasa, university and tradition or culture. Islam Nusantara has many values of character education, including obedience, independence, simplicity, togetherness, the spirit of mutual cooperation, compassion, equality, deliberation, moderation (tawasut) and tolerance (tasamub).
\end{abstract}

Keywords: Character Education, Islamic Archipelago, Islamic Boarding School

\section{INTRODUCTION}

Education is an important asset for the needs of the Indonesian nation, with education it can also help humanity from a life of helplessness to become a human being that is efficient. Education aims to grow quality human resources who can contribute to Indonesia as a dignified country. This is in accordance with the view of Sofyan Mustoip et al in the book "Implementation of Character Education", that education leads humans to a prosperous life and is related to the extent to which humans achieve their life goals. ${ }^{1}$

Education plays a fundamental role as a point of excellence that can grow human character to face various kinds of global challenges. In this case, if Indonesia is able to achieve

\footnotetext{
${ }^{1}$ Sofyan Mustoip et al, Implementation of Character Education, (Surabaya: Jakad Publishing, 2018), 8
} 
success in shaping the strong character of the Indonesian nation, then one day Indonesia will become a superpower in various fields in 2045 or the next 100 years.. ${ }^{2}$

However, in the 21 st century, we are facing an era marked by the development of digital information technology, which is marked by the explosion of information around the world every day. These developments encourage mankind to always be prepared for the possibilities brought by a powerful wave of information. ${ }^{3}$ Incoming information related to issues in each country is easily spread across devices called gadgets via the internet, social media, and other internet-based applications. This has affected the younger generation in Indonesia today or what is commonly referred to as the millennial generation. ${ }^{4}$ The average Indonesian teenager is familiar with and applies the internet in their daily life. However, many of them cannot distinguish between accessing the internet for the positive and avoiding the negative, and are even more likely to be influenced by their social environment in terms of usage.

This is where people complain recently. The country's young generation who should be the figures behind the nation's progress, appear in daily behavior that ignores moral and ethical values. Time goes on, but the impact of globalization is expanding in today's youth culture. Most, especially young people, have been influenced by western culture, western culture has become the "center of attention" of their behavior, so that their personality and way of life as Indonesians are no longer there. Seeing the problems that occur, it is necessary to make efforts to build the character of the country, especially in the social and cultural fields in this century.. ${ }^{5}$

In such circumstances, the great nation and state must immediately improve themselves. If preventive measures are not taken quickly, it is not impossible that the next generation of the nation will become an immoral generation. As a country with the largest Muslim majority in the world, this moral decay is a slap in the face for the Indonesian people, especially for Muslims. In addition, this fact also shows that national education has not succeeded in creating a generation of noble character. So that education reform must be launched immediately, especially for policy makers. ${ }^{6}$

To solve social problems related to national ethics, it is necessary to make education the forerunner and manage it comprehensively. If the state does not pay attention to the education sector, then the state cannot expect changes in the nation's behavior. Education in question means giving freedom to every human being to maintain his life, especially the freedom to be responsible based on the values of life. ${ }^{7}$

Therefore, to overcome the problems of character education mentioned above, one of the efforts to fulfill the character of the Indonesian nation is to implement Islamic character education in the archipelago. Islam Nusantara is an Islamic localization movement that

\footnotetext{
${ }^{2}$ Ibid, 8

${ }^{3}$ Zaenuddin, "Reconstruction of Islamic Educational Institutions Based on Local Wisdom", Zawiyah, Journal of Islamic Thought, Vol. 3 No. 2, (December 2017), 2

${ }^{4}$ Edy Riyanto et al, Implementation of Religious Education and Character Education, (Tangerang: Media Edukasi Indonesia, 2019), 2

5 Ibid, 2-3

${ }^{6}$ Darmaningtyas, Damaged Education, (Yogyakarta: LKiS, 2007), 40-41.

${ }^{7}$ Firdaus M. Yunus, Social Reality-Based Education, (Yogyakarta: Logung Pustaka, 2007), 7
} 
combines cultural values with Islamic values. Islam Nusantara prioritizes gentleness and tolerance in its da'wah, and adheres to the principles contained in Pancasila. Not only that, the Islamic values of the archipelago are reflected in the noble values of Indonesian culture. Often people will obey the cultural values that apply in their area, and even tend to preserve them by passing them on to the next generation. This is in accordance with what Abdurrahman Mas'ud said that cultural values are the potential energy of society' a collective knowledge system in the context of realizing the values of civilized survival, peaceful coexistence, and harmony; live morally, live in love, care for and care for one another. Live in diversity; a life full of forgiveness and understanding, a life of tolerance and compassion, living in harmony with the environment, living with values that lead to enlightenment, and problem solving based on the collective mosaic of reason itself. Such cultural values come from the deepest depths of society. This is the deepest part of local cultural values. nurture and care for one another Living in diversity; live a life full of forgiveness and understanding, a life of tolerance and compassion, living in harmony with the environment, living with values that lead to enlightenment, and problem solving based on the collective mosaic of reasoning itself. Such cultural values come from the deepest depths of society. This is the deepest part of local cultural values. nurture and care for one another Living in diversity; a life full of forgiveness and understanding, a life of tolerance and compassion, living in harmony with the environment, living with values that lead to enlightenment, and problem solving based on the collective mosaic of reason itself. Such cultural values come from the deepest depths of society. This is the deepest part of local cultural values. a life of tolerance and compassion, living in harmony with the environment, living by values that lead to enlightenment, and problem solving based on the collective mosaic of reasoning itself. Such cultural values come from the deepest depths of society. This is the deepest part of local cultural values. a life of tolerance and compassion, living in harmony with the environment, living by values that lead to enlightenment, and problem solving based on the collective mosaic of reasoning itself. Such cultural values come from the deepest depths of society. This is the deepest part of local cultural values. ${ }^{8}$

Islam Nusantara is identified with Islam that is friendly, polite, and integrated with the culture of Indonesian human civilization. Islam Nusantara is a type of Islam that uses a cultural methodology and does not use rigid teachings. Islam Nusantara shows more about the use of culture, cultural preservation, and respect for culture, not cultural oppression. NU has followed the Islamic tradition of the archipelago since its inception. This implies how Islamic teachings can be coordinated with Indonesian socio-cultural customs that have existed since time immemorial. Islam is not bound by erasing existing cultural practices. Islam exists to perfect and idealize the customs of the archipelago. Islam Nusantara was later designed as Pancasila. For NU, Pancasila is a manifestation of Islam Nusantara. ${ }^{9}$ Therefore, it is necessary to explore the values of Islam Nusantara to formulate a model for developing character education methods based on Nusantara Islam.

\footnotetext{
8 Abdurrahman Mas'ud, Towards a Humanist Islamic Paradigm, (Yogyakarta: Gama Media, 2003), 206

${ }^{9}$ HZ Arifin Junaidi et al, Islam Nusantara: Clearing Misconceptions, (Jakarta: LP Ma'arif NU Pusat, 2015), 37
} 


\section{RESEARCH METHODS}

In this paper, the author tries to use a qualitative research method based on the grounded theory method because this study aims to develop existing theories. Grounded theory method is a qualitative research method that aims to develop theories related to the background of research events. ${ }^{10}$ Regarding the type of research, the author uses library research to collect data, analyze and interpret character education in the archipelago from an Islamic perspective. Books, magazines, manuscripts, notes, written historical stories, documents, and other library materials that can be used as reference sources in this writing. ${ }^{11}$

\section{RESULTS AND DISCUSSION \\ THE URGENCE OF CHARACTER EDUCATION}

The term character education is a popular term among Indonesian people today. Many people still rarely define the term character education. Theoretical research on character education can even lead to misunderstandings about the meaning of character education. ${ }^{12}$

The term character education has been widely discussed by experts in the world of education in particular. Various perspectives and meanings are widely spread according to their respective knowledge and experience. Etymologically, the word character comes from the Greek "to mark" which means (to focus). Basically character education consists of two syllables, namely "education" and "character". In simple terms, character education is the formation of a series of attitudes, behavior, personality, character, and character obtained through the education and/learning process. ${ }^{13}$

As stated by Ratna Megawangi, character education is a profession to educate children so that they can make wise decisions and practice them in an orderly daily life, so that they can make a positive contribution to their environment. ${ }^{14}$ Another definition put forward by Muchlas and Hariyanto, from a simple point of view character education is everything that is positive that is done by the teacher and affects the personality of the students he teaches. Character education is a conscious and sincere effort from a teacher to teach good values to his students. ${ }^{15}$

Based on the above definition, the authors conclude that character education is a conscious effort to instill, educate and develop good values in children so that they can apply positive behavior in everyday life.

\footnotetext{
${ }^{10}$ Burhan Bungin, Qualitative Research Data Analysis, (Jakarta: PT. Raja Grafindo Persada, 2003), 11

${ }^{11}$ Sugiyono, Educational Research Methods: Quantitative, Qualitative Approaches, and R and D, Cet. VIII; (Bandung: Alfabeta, 2009), 296

12 Dharma Kesuma et al, Study of Theory and Practice of Character Education in Schools, (PT. Teen Rosdakarya, Bandung: 2011), 5

13 Meyke Garzia, "The Urgency of 21st Century Character Education in Early Childhood”, Proceedings of the 2018 National Basic Education Seminar and Discussion, 358

14 Ratna Megawangi, Character Education, The Right Solution to Build the Nation, (Indonesian Heritage Foundation, Bogor: 2004), 95

15 Muchlas Samani and Hariyanto, Concepts and Models of Character Education, (PT. Teen Rosdakarya, Bandung: 2011), 43
} 


\section{ELEMENTS FOR CHARACTER}

Character is formed through a process that lasts throughout life. The elements that make up the character include: Vision, mission and life goals, principles, values, paradigms, habits and virtues. Character building begins with a vision. Based on this vision, we can formulate a mission. If we have a mission then we can define a goal. From the goal we have principles. Principles play a major role in the behavior that we will do or not do, because they are valuable or not valuable in order to realize the vision, carry out the mission and achieve life goals. ${ }^{16}$

\section{Vision}

The vision of life is a picture of ourselves in the future that we have started to realize from now on. Vision can be about yourself, other people, families, institutions, companies, organizations, communities, nations, countries and even the world. If we apply the understanding of our vision to each of us, our personal vision answers the question "what kind of human do I want to be and what kind of product and/or service do I want to contribute to other people, other people, the community. , society in this life?". For example, our personal vision, we define as a human being who can be trusted and relied on.

\section{Mission}

Life(mission) is the main activity that we do to realize the vision. With a mission we state to ourselves, what is the main thing that we do so that our vision of life is realized and we succeed in becoming the human being as embodied in our vision of life. Humans can be trusted personally and relied on in the tasks and jobs entrusted to them. Based on this vision of life, we can formulate our life mission, for example continuously developing ourselves and our abilities. The mission of life is the capital to live life. If you have a mission in life, you will live your life purposefully, meaningfully, productively but relaxed, calm, calm, serious and serious but not tense. Mission must be in the form of a verb.

Aim

With our vision of life, we describe the future that we have started to strive for from now on. With a mission we set the main activities to fight for and realize the vision. With the purpose of life (life purpose), we determine what we will achieve in real terms by realizing the vision of life, the mission is achieved. Based on our vision and mission, we set goals, for example to prosper ourselves, others, the community and society.

\section{Principles of life}

The principle (principle) comes from the Latin word principium or the English word principle which means "beginning" or starting point. Principles are the starting point for thinking and acting. The principle of life becomes the basis of the foundation and reason for living life, behaving, acting and acting. From the vision, mission and purpose of life, we have a clear direction in life. From there was born in us the principle of life. With the principle of life, we have a basis and basis for assessing activities, work, lifestyle, housing facilities and infrastructure, such as food, clothing, houses, which vehicles will help us realize our vision, carry out our mission, and achieve our life. target.

16 AM Mangunhardjana, Character Education: Material Objectives, Methods and Models, (Yogyakarta: Grahatma Semesta, 2016), 34-37 


\section{Score}

Value means the price, weight, quality, quality that exists in humans, animals, plants, goods, events or circumstances. If the principle has been united and united with oneself and made private property, then the principle becomes a personal value. So value is a principle that has been made private. Values are subjective according to society, even the community, society, nation that owns it. While the principle remains objective, because it applies anywhere, anytime in any business, with anyone, and under any conditions. The principle is the law of hot iron, smoldering heat, whoever touches it must be exposed to the heat. For example, if our hands touch the iron, our hands will blister and even burn. But after being rated, ${ }^{17}$

\section{Paradigm}

Values affect the way we see, perceive and behave and behave when dealing with the realities of life, both humans and animals, goods, events, or circumstances. The word paradigm comes from the Greek paradeiknynai which means "to show or show two things at the same time, one next to the other. From that word, the word paradigm is formed, which in Indonesian becomes a paradigm, which means an example, an example, a pattern, especially an example of a superior pattern. -the values we hold and rank the values we set.

\section{Behavior}

Behavior (behavior) is everything we do and we make and can be observed and recorded by anyone, and for any purpose. Our behavior has to do with everything we do for ourselves, for example, the types of food and drink and how we eat and drink them. It has to do with the shape of the cut and the way we style our hair, the color of our clothes and the way we dress, the things we say and the way we say them, the kinds of hobbies or games we like, the kinds of reading we like and the way we read them. From our behavior and the way we do it, our personalities, attitudes, interests, talents, values and value systems, motivations, and zest for life, our ambitions and the things we strive for are revealed.

\section{Habit}

Habits are the fruit of behavior that we always do, repeatedly, continuously, diligently, consistently, which is carried out over a long and long period of time, so that behavior is ingrained in us, almost becomes our instinct and second nature. Because of that habit we can do it easily and spontaneously and we do it the same way every time we do it. Habits allow us to do so without thinking, remembering and planning ahead of time, and easily bearing the fruit we desire. Habits stick and become one with us and characterize our behavior and ourselves. ${ }^{18}$

\section{THE NATURE OF ISLAM NUSANTARA}

On a practical level, the true typology of Islam Nusantara has long been reflected in the archipelago. By considering local traditions or culture, ways of thinking, understanding and practicing Islamic teachings, so that they can reveal the uniqueness of the Islamic style of the

\footnotetext{
17 Ibid, 38-41

${ }^{18}$ Ibid, 42-45
} 
archipelago and distinguish it from other Islamic styles in addition to its substance content, both in the Middle East, India, Turkey, and so on.

Islam Nusantara is part of the subculture built by Islam. Islam is actually friendly, polite, and integrated with the culture of Indonesian human civilization. Islam Nusantara is a type of Islam that uses a cultural methodology and does not use rigid teachings. Islam Nusantara prioritizes the use of culture, cultural preservation, respect for culture, not cultural oppression. Meanwhile, Islam Nusantara is the identity of Islamic ideas put forward by Nahdlatul Ulama (NU). The concept of movement and da'wah promoted by the Nahdlatul Ulama (NU) scholars cannot be separated from the traditions of previous scholars who are associated with the model of Ustadz Walisongo. This is a characteristic of the Nahdlatul Ulama (NU) da'wah which aims to develop a harmonious Islam with local characteristics, customs and culture. ${ }^{19}$

In recent years, Islam Nusantara has become increasingly popular because it became the main theme of the 33rd Nahdatul Ulama (NU) Congress which was held in Jombang, East Java, from August 1 to 5, 2015. While NU represents mainstream Muslims in Indonesia, Islam Nusantara is increasingly promoted in the wider Indonesian Muslim community, extending from urban to rural communities. Of course, the main theme of Islam Nusantara in the congress is a response to the declining image of Islam in the international arena, and even tends to be considered negative. ${ }^{20}$

According to Teuku Kemal Pasha in his article "The Poetic and Cultural Dimensions of the Islamic Archipelago", provides an explanation that is no less interesting. He defines Islam Nusantara as a process of appreciating and practicing the place where people live in the archipelago. The thickness of the word "Nusantara" is not only an affirmation of place names or nouns, but what is more important is an explanation of the differences in the adjectives or characteristics of Islam "here" and Islam "there". The success of Islam as a peaceful Nusantara religion cannot be separated from the adaptability and resilience of local wisdom, art and culture. Unlimited theological beliefs fit into the cultural dimensions of the people and resonate through local knowledge. ${ }^{21}$

Simply put, according to Arifin Junaidi, Islam Nusantara means Islam that has existed in Indonesia from the past until now which was taught by Walisongo, Islam ngono iku seng digoleki (this is what Islam is looking for), Islam is peaceful, Guyub (rukun), ora petentengan (not against Islam). ). -mentang) and Islam that is rahmatan lil'alamin, Walisongo spread the teachings of Islam, and they correctly understood this teaching from the teachings of the Prophet Muhammad SAW. Walisongo not only invites oral bil, but also bilhal, no matter the form, but the essence of Islam. ${ }^{22}$

Therefore, Islam Nusantara is not limited to the history or place of Islam in Java. More importantly, Islam Nusantara is a religious leader or role model who must always fight for the

\footnotetext{
${ }^{19}$ Said Aqil Siradj, Affirming Islam Nusantara, (Jakarta: LP Ma'arif, 2015), 4

20 Mujamil Qomar, ISLAM NUSANTARA: An Alternative Model of Thinking, Understanding, and Islamic Practice, El-Harakah JournalVol.17 No.2 of 2015, 199

21 Teuku Kemal Pasya, The Poetic and Cultural Dimensions of Islam Nusantara”, Opinion Kompas, 4 August 2015.

${ }^{22}$ HZ Arifin Junaidi et al, Islam Nusantara: Clearing Misconceptions, (Jakarta: LP Ma'arif NU Pusat, 2015), 28
} 
future of civilization in Indonesia and the world. Nation and state. A dynamic and friendly Islam with a diverse cultural, subcultural and religious environment. Islam is not only suitable for the people of the archipelago, but also worthy of coloring the culture of the archipelago to achieve its inclusiveness, namely rahmatan lil'alamin.

\section{THE CONCEPT OF CHARACTER EDUCATION WITH ISLAMIC INSIGHTS OF THE NUSANTARA}

The process of forming Nusantara Islam-based character education that we have lived so far has several forms. That's why we at Nahdlatul Ulama as well as the pioneers of Islam Nusantara always convey the teachings of Islam Nusantara, both formally and informally. ${ }^{23}$ There are at least five Nusantara Islam-based character education that we have carried out and cannot be denied, including:

\section{Boarding school}

Pesantren is an institution that maintains the tradition of scholars, because of this closeness to the land, water, sea, forests, mountains, and natural resources owned by the archipelago. in the future. Prospective leaders of the nation are recruited to become protectors, protectors, protectors and custodians of this nation's cultural traditions. Not only that, they are also in cadres to understand and know the condition of the common people under them, to be able to interact with them, then to follow the lifestyle of the ulama around the community and local residents. Islamic boarding schools maintain national unity and integrity. The people who live in the pesantren show unity to the children of the Nation. KH. Saifudin Zuhri said the tradition of the yellow book is the glue of Islam in the archipelago and implies the glue of our ethnic group. One of the instruments of unity that was raised among Islamic boarding schools was the nomad students. Nomad students form national organizations and also unions between various components of the nation. From the explanation above, it can be concluded that pesantren is part of the concept of Islamic-based Nation character education in Nusantar. ${ }^{24}$

\section{Madrasa}

The word "Madrasab" comes from Arabic which means a place of learning, which comes from the root word darasa. The name or mention of an Islamic religious school, a formal Islamic teaching and learning process that has classes (including facilities such as tables, benches and blackboards) and classic forms in the curriculum. The synonym of madrasa in Indonesian is religious school. Literally, madrasa is defined as a place for student learning or a place to teach. Technically the same, namely in formal language called the teaching and learning process. In Indonesia Madrasas are no different from schools, but in Indonesia madrasas are not necessarily understood as schools, but are given a more specific connotation, namely religious schools, where students learn things or the ins and outs of Islamic teachings. ${ }^{25}$

\footnotetext{
23 Achmad Syahid, Islam Nusantara Religion-Cultural Relations and the Trend of Ulama's Power, (Depok: Rajawali Pers, 2019), 19

${ }^{24}$ Said Aqil Siradj, Islam a Source of Cultural Inspiration for the Archipelago, (Jakarta: LTN NU, 2014), 3

${ }_{25}$ Djamaluddin, Islamic Religious Education, Madrasahs, Schools and Islamic Boarding Schools, (Yogyakarta: Pustaka Pelajar, 2007), 8
} 
In general, madrasas are a form of development of traditional Islamic learning models, more specifically madrasas that have been established since the seventeenth century can be called the early days of the establishment of madrasa education organizations. In fact, many pesantren actually maintain their originality (salaf) without turning into madrasas. In general, madrasas have a close relationship with pesantren, because madrasas are really an order of religious teachings adopted from Western systems and models. Previously, pesantren was the only formal religious education organization. Towards the beginning of the 20th century, when Indonesian Muslims began to be moved by the reform movement, madrasas began at the public school level. ${ }^{26}$

Madrasas are Islamic educational institutions. In it tafaqquh fi al-din is an important component. Keeping the treasures of madrasas also seems to mean maintaining the tafaqquh fi al-din component. ${ }^{27}$ Madrasas in Indonesia, as part of Islamic educational institutions, have perfectly and without exception inherited the characteristics and characteristics mentioned above, both unique and seen from their substance content, or even developed by the people who raised them. they. culture. It is no exaggeration to say that the historical background of the madrasa has been on a consistent path since its inception until today. ${ }^{28}$

\section{Integrated Islamic School}

Integrated Islamic Schools are different from pesantren and madrasas because they have certain characteristics that are easily recognizable. First, these Integrated Islamic Boarding Schools are generally located in urban areas, crowded areas or elite settlements. Second, elite from an academic point of view, in some cases only the best students can be admitted after going through a rigorous selection test. Third, this type of school has good teaching staff, disciplined, competitively selected and only those who meet the qualifications can be accepted to teach. Fourth, the facilities and infrastructure owned by the Integrated Islamic Boarding School are generally much better and more complete, such as libraries, laboratories, computer rooms, worship facilities, sports and other supporting facilities. Fifth, this Integrated Islamic School is more expensive than schools in general. Registered students are subject to various fees such as registration fees, monthly tuition fees, building fees, and other activity funds set by the school or foundation. Sixth, because this Integrated Islamic School is an elite (or superior) school, students generally come from rich, elite families or can be called the Muslim middle class. ${ }^{29}$

This Integrated Islamic School is motivated by the awareness of the Muslim middle class, especially Muslims in urban areas, that Islamic educational institutions, pesantren and madrasas that were established were considered less successful in delivering students to the care of science and technology, although it is recognized that Islamic boarding schools and madrasas are very effective in fortifying children from moral decay. This awareness is filled

\footnotetext{
${ }^{26}$ Ibid, 12

${ }^{27}$ Arief Subhan, Indonesian Institute of Islamic Education, (Jakarta: Kencana Prenada, 2012), 71

28 Djamaluddin, Islamic Religious Education, Madrasahs, Schools and Islamic Boarding Schools, (Yogyakarta: Pustaka Pelajar, 2007), 18

${ }^{29}$ HS. Mastuki, Awakening of Santri Cendikia, (Ciputat: Pustaka Compas, 2016), 267
} 
with the desire and ideals of Muslims to create a prototype of Islamic education that is characterized by modern and superior in the fields of science and technology.

\section{College}

Higher Education is an educational unit that organizes higher education (Law of the Republic of Indonesia Number 2 of 1989 concerning the National Education System, hereinafter abbreviated as Law 2 of 1989 article 16 paragraph (2) of Government Regulation Number 30 of 1990 concerning Higher Education - hereinafter abbreviated as PP 30 of 1990 article 1 paragraph (2). ${ }^{30}$

Higher education is a continuation of secondary education which is organized to prepare students to become members of the community who have academic and professional abilities who can apply, develop, and create science, technology, and art. Higher education can also be interpreted as a higher level than secondary education in the school education pathway which aims to develop and disseminate science, technology, art and seek its use to improve people's living standards and enrich the nation's culture. ${ }^{31}$

\section{Culture}

Islam Nusantara is a cultural infrastructure built by Islam. Islam that is integrated with culture does not use rigid doctrines. Islam Nusantara promotes cultural use, cultural protection, respect for culture, not cultural oppression. Tradition is a hereditary habit that is still ongoing in society today. Before the arrival of Islam, the Muslim community was familiar with various beliefs. Deep-rooted beliefs that have been passed down from generation to generation cannot simply be dispelled. Therefore, Islamic tradition is a cultural blend between Islamic teachings and customs that exist in the archipelago. The Islamic tradition of the archipelago is one form of da'wah practice practiced by the scholars at that time. Ulima has not completely erased the existing customs in society.

The Islamic culture of the archipelago has a positive value in maintaining the unity of local and Islamic culture, so that it is able to fight globalization, westernization and radicalism. The emergence and development of Islam in Indonesia cannot be separated from the long historical ties in the country. Before the emergence of Islam, the people of the archipelago were familiar with and implemented a cultural and religious system that was so complex and international. Various forms of culture and religious customs have merged into the distinctive colors of this equatorial country. On the other hand, every cultural system and strategy is difficult or impossible to remove the richness of local culture from its roots in any way. ${ }^{32}$

Nusantara Islamic culture has values that have relevance to Islamic religious education, because in it there are a number of religious values that can fill the lack of content of Islamic religious education. In other terms, the acculturation process between Islam and local culture then gave birth to what is known as local genius, namely the ability to absorb as well as carry out active selection and cultivate foreign cultural influences, so that a unique new creation can be achieved, which is not found in the territory of the

\footnotetext{
${ }^{30}$ M. Agus Hardjana, Tips for Studying Success in Higher Education, (Yogyakarta: Kansius, 1994), 9

${ }^{31}$ Ibid, 10

${ }^{32}$ Nurhuda, Modern Islamic Boarding Schools and Madrasas. (Bandung: Youth Rozdakarya, 2016), 39
} 
nation. cultural influence. On the other hand, local genius has characteristics such as: able to withstand foreign cultures; have the ability to accommodate foreign cultural elements; ${ }^{33}$

\section{THE VALUE OF CHARACTER EDUCATION WITH ISLAMIC INSIGHTS OF THE NUSANTARA}

Islam Nusantara is a cultural infrastructure built by Islam. Islam is friendly, polite, and integrated with culture like Indonesian civilization. Islam Nusantara is a type of Islam that uses a cultural approach and does not use rigid doctrines. Islam Nusantara promotes cultural use, cultural protection, respect for culture, not cultural oppression. The values of character education in Islam Nusantara, especially in pesantren, are many, including:

\section{Obedience}

A santri must obey the kyai and his teacher. For students, kyai and teachers are murobbi ruhihi or people who instill goodness in their souls. His status is even higher than his parents, because if his mother and father are biological parents, then the guru or kyai are spiritual or spiritual parents. Once again, the kyai or teacher is not only a person who acts as a mediator or transfer of knowledge, but a kyai is a person who guides the soul and equips students with religious knowledge, as well as being an example in all aspects of life. . The existence of the kyai as murabbir-ruh requires students to give sincere obedience and obedience; showed unrelenting respect, and once again unquestionably carried out all the duties assigned to him. ${ }^{34}$

\section{Independence}

As an important characteristic of pesantren, independence is also one of the main characteristics of santri. In pesantren, students are taught to manage themselves, they are accustomed to managing time and choosing friends according to their tastes. As a result, since they first came, the students forced themselves to take care of and fulfill all their needs. In this case, the most important aspect of personality is of course the problem of maturity, namely how students or students are not used to complaining and are easy to complain about everyday problems. This aspect further encourages students to be honest, smart, skilled, creative and disciplined, and face everything on their own. ${ }^{35}$

\section{Simplicity}

Simplicity is also the most important aspect of the character of the santri. Since pesantren are generally managed by the private sector, the lack of facilities is of course a common problem. Simplicity makes students familiar with qona ah rather than overdoing it. Simplicity also teaches students to get used to seeing each other as equals without discriminating against their social status. This aspect then encourages students to adapt to the status quo and teaches students to live anywhere.

\section{Togetherness in the Family}

The attitude of unity and affection is also a distinguishing feature of students from other students. This attitude arises because student life requires them to get along, interact

\footnotetext{
${ }^{33}$ Ibid, 47

${ }^{34}$ Durrotun Nasikhin, Internalization Process of Nusantara Islamic Character Values, Turatsuna Journal, Volume 21 No. August 2, 2019, 22

35 Ibid, 23
} 
and live side by side in various forms of activities. Of course, there are ups and downs in interpersonal relationships. This is what gives color and strengthens ukhuwwah between them, like a family. This attitude in turn will lead to unity, solidarity, tolerance, mutual cooperation, mutual cooperation, and mutual cooperation in all things, even though they have completed their studies at Islamic boarding schools. This character will make Santri a tough and tough person and ready to live in society. If santri can transfer their character and personality to the wider community, of course they can automatically add color to life in this country.

\section{The Spirit of Mutual Cooperation}

The term gotong royong seems to have begun to be forgotten lately, along with the growing individualistic attitude of society, the fading of Pancasila ideology, the value of brotherhood between brothers and sisters of the same religion seems to be fading, even though most of our society as Muslims, this clearly teaches us to respect each other. love. Moreover, other religions should teach the same thing. Gotong royong is a native Indonesian culture that is very in line with religious teachings, so if we develop a culture of gotong royong again it will be very good, then one way to repeat the culture of gotong royong is to study in Islamic boarding schools, because in Islamic boarding schools they are still taught the culture of gotong royong. . It even becomes a value that shows that students always hold fast to unity or cooperation. ${ }^{36}$

\section{Sowan to Kyai/Teacher}

Sowan is a tradition of gathering santri with kyai, the aim is to simply ask for prayer, or seek fatwas, solutions and instructions for the problems faced, or even just face to face. The Sowan tradition is a santri character that is formed after studying at a boarding school, has not been studied elsewhere, and of course has become part of the character education of Islam Nusantara. Sowan can be completed by students individually or together. Usually Kyai will receive guests gracefully.

\section{Affection}

Affection is a feeling that grows in the heart, where a person is sincere and sincere to make the person he loves happy. Love is not only for lovers, but also for parents, family, friends and other living beings. Family affection appears in the form of sympathy and sympathy for loved ones, naturally without a mature design. For example, love between husband and wife requires responsibility, sacrifice of honesty, mutual trust, mutual understanding, and mutual openness. Therefore, love gives true human meaning. Sincere feelings are characterized by a sincere desire to give more than receive, and put aside their own interests to make loved ones and loved ones happy.

\section{Equality}

Society is divided into several layers: upper, middle and lower. Each layer is further divided into top layers: top top, top middle, bottom top, middle layers: top middle, middle middle, and bottom middle, and bottom layers: top bottom, bottom middle, and bottom bottom. The top layer has the least amount, the middle layer has the largest number, and the bottom layer has the largest number. The basis of stratification can be from heredity:

\footnotetext{
${ }^{36}$ Ibid, 24
} 
blue blood and common blood, priyayi and commoners: inside and outside adat. The beliefs of the rich, the rich middle class, and the poor poor. Educated by highly educated people. Number of religious adherents: majority and minority. Serve society and society: heroes, great people, ordinary people.

\section{Discussion}

Deliberation is generally considered a basic social and national principle. In addition, in principle the Qur'an states that this teaching is one of the examples of the Prophet Muhammad SAW in solving religious and social problems. In everyday life, this kind of discussion can also be understood as a forum where people can discuss, exchange ideas, form opinions, and solve problems together.

\section{Tawasuth (Tolerance)}

Tasamub is a tolerant attitude towards differences, be it religion, ideology, belief, society, culture, and various other differences. Diversity is an unavoidable reality. Is a unit, as a place to stay in touch, socialize, adapt, and interact so as to create a complete atmosphere. Tolerance towards religion does not mean a compromise attitude towards belief, because belief is a complete truth that cannot be mixed with other religious beliefs, nor can it maintain the truth of erroneous and misguided religious beliefs. Tolerance becomes a natural law that refines differences into grace. In terms of culture, culture is essentially a product of human rationality, has noble values, is historical archeology,

\section{Tawasuth (Medium)}

Tawassuth is a feature of diversity and will not stay at extremes. An attitude that can absorb all the good things from different groups. The ability to appreciate goodness and truth. Or it can be understood as a humble attitude based on the principle of life that emphasizes the need to maintain justice and integrity in living together. Nahdlatul Ulama with this basic attitude will always be a role model group, they behave straightly, always constructively, and avoid all forms of tatharruf (extreme) methods. ${ }^{37}$

From the explanation above, according to the author, the values of character education based on Islam Nusantara are values that must be possessed by students and are often found or studied in Islamic boarding schools and the community. Instilling character values based on Nusantara Islam is not only to be studied and then become a science, but it is necessary to apply, exemplify, habituate and civilize, so that it continues to provide benefits to students in particular and to society in general. As explained above about the values of character education in Islam Nusantara, the author argues that in building the nation's character education it is necessary to adopt or integrate with the values of Islam Nusantara. According to the author, Character education that is being carried out at this time has not been able to shape the character of students in accordance with the goals of national character education. Therefore, one of the authors argues, if character education is to be applied universally, it is necessary to adopt the values of Islam Nusantara, in this case the concepts that have been applied are pesantren and madrasas.

${ }^{37}$ Ibid, 27 


\section{STEPS TO MAINTENANCE AND DEVELOPMENT OF CHARACTER EDUCATION BASED ON ISLAM IN THE NUSANTARA}

In order to maintain and develop Nusantara Islam-based character education, there are five things we need to do, including:

\section{Developing National Character Education}

Carry out national character education. The character of this nation is based on a strong attitude and identity, and is not easily influenced by external trends and problems. The nation's moral education can be done by instilling noble moral values to all levels of society, especially the younger generation. These noble ethical values come from various existing norms, especially religious norms that develop in Indonesia. Then included in school subjects. National character education can also be developed from local cultural wisdom. Local cultures such as mutual cooperation, mutual respect, hard work and shame must be revived at all levels of society. Thus, the character of the Indonesian nation will grow back, and this nation will regain its original identity.

\section{Revitalizing the Roles and Functions of Islamic Boarding Schools}

Pesantren is the original culture of the archipelago, and has developed the values of the archipelago that are sustainable to this day. To keep up with the times, we must reactivate the roles and functions of pesantren, but we still maintain the old concept or not. As we all know, pesantren is the oldest educational institution in the country. He describes the nation's character who is polite, wise, and has character. But recently, the name of the Pesantren has been tarnished due to incidents of several people involved in terrorist movements. Therefore, it is time to optimize the role and function of Islamic boarding schools/surau/dayah as candradimuka craters for Islamic education in Indonesia. In addition, it also functions as a builder for the moral development of the nation's generation.

\section{Increase studies and research on Indonesian Islam.}

In strengthening Islamic studies in Indonesia, research can be carried out by government agencies such as LIPI or the Ministry of Religion and the Ministry of Research and Development of National Education, or by private institutions, especially Islamic universities. This research focuses on extracting scientific treasures, ancient manuscripts, buildings and cultural relics left by the ancestral scholars of the Indonesian state. The results of the research are then disseminated to all levels of society in a programmed and sustainable manner, so that they are able to understand the intellectual property and wisdom of the scholars and the founders of the country.

\section{Building a critical attitude}

The formation of this critical attitude is based on the principle of amar ma'ruf nahi munkar, because it emphasizes that the attitude of Islam Nusantara towards the state is absolute obedience, and the state must be protected and defended through education or noneducation. by upholding customs, culture and traditions. All movements that threaten our country, for the adherents of Islam Nusantara have an obligation to defend and defend the country.

\section{Strengthening Nusantara Islam}

Affirmation of Islam in the archipelago is important for carrying out character education, because so far the public sphere is filled with radical Islam which emphasizes 
violence more than prioritizing brotherhood. It is undeniable that they have also penetrated the lower ranks of Ulama, so that the penetration of radicalism has also caused several internal conflicts among Ulama. This situation is of course also a big challenge for PBNU to implement Nusantara Islam among Nabdliyin residents.

In summary, the author believes that the five efforts above must be supported by all parties, including government and private institutions, both individually and collectively. By doing the four things above in a serious, planned and sustainable manner, the great hope for the revival of the distinctive doctrine of Islam in the wave of modernization will be realized in this country.

\section{CONCLUSION}

Islam Nusantara tries to prevent religion and culture from defeating each other, but instead manifests it in a religious reasoning model that no longer gets its original form from religion, and tries to connect the bridges that have been separating religion and culture so that there is no longer a conflict between religion and culture. Pesantren is a representative of Nusantara Islam-based character education. Pesantren teaches students to always respect cultural traditions developed based on Islamic teachings. Meanwhile, Islam Nusantara has many values of character education, including obedience, independence, simplicity, unity, the spirit of mutual cooperation, compassion, equality, caring, tenderness (tawasut) and tolerance (tasamuh).

\section{REFERENCES}

Azisi, Ali Murshid. "Islam Nusantara: Indonesian Islamic Patterns and Its Role in Indonesia" Confronting the Puritans",Journal of Islamic Thought and Culture Vol. 29 No. 2 July 2020

Bungin, Burhan. Qualitative Research Data Analysis, Jakarta: PT. Raja Grafindo Persada 2003. Darmaningtyas. Damaged Education, Yogyakarta: LKiS 2007.

Djamaluddin. Islamic Education, Madrasas, Schools and Islamic Boarding Schools, Yogyakarta: Pustaka Pelajar, 2007

Hardjana, M. Agus. Tips for a successful study at a university, Yogyakarta: Kansius 1994

Junaidi, HZ Arifin et al. Islam Nusantara: Clearing Misunderstandings, Jakarta: LP. Ma'arif NU Center 2015.

Lestari \& Qudus, Abdul. Genealogy of Modern Islamic Thought in the Archipelago, Mataram: Sanabil, 2017

M. Yunus, Firdaus. Social Reality-Based Education, Yogyakarta: Logung Pustaka 2007.

Mas'ud, Abdurrahman. Towards a Humanist Islamic Paradigm, Yogyakarta: Gama Media 2003.

Mastuki, HS. The Awakening of Cendikia Santri, Ciputat: Compass Library, 2016

Mowoka, Samuel Charlies. "Islam of the Archipelago and Islam in the Archipelago: The Development of Islam Since Its Entry Until Now",Lantern Journal Vol. 19 No. March 1, 2020 
Mulyadi, Nusantara Islamic Philosophy: Perspectives of Syed Muhammad Naquib Al-Attas, Lhokseumawe: Unimal Press, 2018

Mustamir, Ahmad Khoirul. "Islam Nusantara: Nahdlatul Ulama's "People's" Struggle Strategy".Intellectual Journal: Journal of Islamic Education and Studies Volume 9, Number 3, December 2019

Mustoip, Sofyan et al. Implementation of Character Education, Surabaya: Jakad Publishing, 2018.

Nurhuda. Modern Islamic Boarding Schools and Madrasas. Bandung: Rosdakarya Youth, 2016

Qomar, Mujamil. "Islam Nusantara: An Alternative Model of Thought, Understanding, and Islamic Practices", Journal of El-HarakahVol.17 No.2 Year 2015

Riyanto, Edy et al. Implementation of Religious Education and Character Education, Tangerang: Indonesian Educational Media 2019

Romli, Mohamad Guntur. Islam Kita, Islam Nusantara: Five Basic Values of Islam Nusantara, Tangerang: Ciputat School Publisher. 2019

Siradj, Said Aqil. Islam is the Source of Inspiration for Indonesian Culture, Jakarta: LTN NU, 2014

Subhan, Arief. Indonesian Islamic Education Institute, Jakarta: Kencana Prenada 2012

Sugiyono. Educational Research Methods: Quantitative, Qualitative Approaches, and R and D, Cet. VIII Bandung: Alphabeta 2009.

Shahid, Ahmad. Islam Nusantara Religion-Cultural Relations and the Tendency of the Power of Ulama, Depok: Rajawali Pers 2019.

Zaenuddin. "Reconstruction of Islamic Educational Institutions Based on Local Wisdom", Zawiyah, Journal of Islamic Thought, Vol. 3 No. 2. December 2017. 